\title{
IDENTIFIKASI KUALITAS AIR TANAH DANGKAL DI SEKITAR TPA SUNGAI RAYA
}

Windry Cinde Septia ${ }^{1)}$ Arifin $^{1)}$ Yulisa Fitrianingsih ${ }^{1)}$

${ }^{1)}$ Program Studi Teknik Lingkungan Jurusan Teknik Sipil Fakultas Teknik Universitas Tanjungpura, Pontianak Email : windry.cinde@gmail.com

ABSTRAK
Salah satu dampak yang dihasilkan dari aktivitas di TPA adalah air lindi. Lindi merupakan cairan yang dihasilkan dari dekomposisi sampah yang bercampur dengan air hujan. Tempat Pemrosesan Akhir (TPA) Sungai Raya terletak di Desa Kuala Dua Kabupaten Kubu Raya. TPA Sungai Raya beroperasi dengan sistem open dumping. Open Dumping merupakan pengelolaan sampah dengan cara membiarkan sampah dan ditumpuk pada suatu lapangan terbuka Sistem ini dapat memberikan dampak terhadap lingkungan, salah satunya pencemaran air yang disebabkan oleh air lindi yang tidak terkelola dengan baik. Tujuan dari penelitian yaitu untuk mengidentifikasi kualitas air tanah di sekitar TPA dan untuk mengetahui pengaruh jarak TPA terhadap kualitas air di sekitar TPA Sungai Raya. Pengambilan sampel dilakukan pada 3 wilayah disekitar TPA yaitu wilayah A sebanyak 6 titik sampel, wilayah B sebanyak 6 titik sampel dan wilayah C sebanyak 6 titik sampel. Total titik sampel yang digunakan sebanyak 18 titik dengan masing-masing jarak 10 meter tiap antar titik. Metode yang digunakan yaitu melalui pendekatan observasi, analisis hasil laboratorium dan uji statistik dengan minitab (Uji Mann Whitney). Standar baku mutu air yang digunakan yaitu standar baku mutu air kelas II PP No.82 Tahun 2001 yang diperuntukkan untuk kegiatan MCK (Mandi,cuci,kakus). Hasil yang diperoleh menyatakan bahwa pada wilayah A nilai konsentrasi tertinggi berada pada titik $A 1$ yang merupakan titik terdekat dengan tumpukkan sampah pada TPA yaitu dengan nilai konsentrasi $\mathrm{COD}, \mathrm{Pb} \mathrm{Cd}$ dan total coliform berturut-turut sebesar 718,7 mg/l; 0,03 mg/l; 0,04 mg/l; dan $4300 \mathrm{MPN} / 100 \mathrm{ml}$, sedangkan nilai konsentrasi terendah berada pada titik A6 yang merupakan titik dengan jarak 50 meter dari titik A1 dengan nilai konsentrasi $\mathrm{COD}, \mathrm{Pb} \mathrm{Cd}$ dan total coliform berturut-turut sebesar $114,5 \mathrm{mg} / \mathrm{l} ; 0,01 \mathrm{mg} / \mathrm{l}$; $0,000 \mathrm{mg} / \mathrm{l}$; dan $2850 \mathrm{MPN} / 100 \mathrm{ml}$. Pada wilayah B nilai kosentrasi tertinggi berada pada titik B1 yang merupakan titik terdekat dengan tumpukkan sampah pada TPA dengan nilai konsentrasi $\mathrm{COD}, \mathrm{Pb}$ Cd dan total coliform berturut-turut sebesar 699,0 mg/l; 0,03 mg/l; 0,02 mg/l; dan 3750 MPN/100ml, sedangkan nilai konsentrasi terendah berada pada titik B6 yang merupakan titik dengan jarak 50 meter dari titik B1 dengan nilai konsentrasi COD, Pb Cd dan total coliform berturut-turut sebesar $62,5 \mathrm{mg} / \mathrm{l} ; 0,00 \mathrm{mg} / \mathrm{l} ; 0,000 \mathrm{mg} / \mathrm{l}$; dan $2650 \mathrm{MPN} / 100 \mathrm{ml}$. Wilayah C nilai kosentrasi tertinggi berada pada titik C1 yang merupakan titik terdekat dengan tumpukkan sampah pada TPA dengan nilai konsentrasi COD, $\mathrm{Pb}$ Cd dan total coliform berturut-turut sebesar 700,3 mg/l; 0,03 mg/l; 0,03 mg/l; dan $4950 \mathrm{MPN} / 100 \mathrm{ml}$, sedangkan nilai konsentrasi terendah berada pada titik $\mathrm{C} 6$ yang merupakan titik dengan jarak 50 meter dari titik $\mathrm{C} 1$ dengan nilai konsentrasi COD, Pb Cd dan total coliform berturut-turut sebesar 125,2 mg/l; 0,01 mg/l; 0,000 $\mathrm{mg} / \mathrm{l}$; dan $3800 \mathrm{MPN} / 100 \mathrm{ml}$. Nilai konsentrasi rata-rata COD dan total coliform pada tiap titik berada di atas baku mutu air kelas II PP No.82 Tahun 2001, sedangkan nilai konsentrasi rata-rata $\mathrm{Pb}$ berada dibawah ambang batas baku mutu air kelas II PP No.82 Tahun 2001 dan nilai CD pada titik yang berada didalam TPA berada di atas ambang batas baku mutu air kelas II PP No.82 Tahun 2001, serta nilai Cd yang berada diluar TPA bernilai dibawah ambang batas baku mutu air kelas II PP No.82 Tahun 2001. Hasil uji statistik Mann Whitney menunjukkan nilai signifikan $>0,05$. Angka tersebut mengindikasikan bahwa terdapat perbedaan yang nyata (signifikan) antara jarak TPA terhadap kualitas air tanah dangkal di sekitar TPA Sungai Raya. Berdasarkan hasil analisis, terdapat pengaruh jarak TPA terhadap kualitas air tanah dangkal disekitar TPA Sungai Raya, yang ditunjukkan dengan semakin jauh dari TPA, nilai kualitas air tanah dangkal semakin membaik.

Kata Kunci :Air Lindi, Kualitas air tanah dangkal, TPA

\section{ABSTRACT}

One of the impacts resulting from activity in the landfill site is leachate. Leachate is the liquid produced from the decomposition of wastes mixed with rain water. Sungai Raya Landfill Site is located in Kuala Dua Village, Kubu Raya District. Sungai Raya Landfill Site operates under an open 
dumping system. Open dumping is a waste management by allowing waste stacked in an open field. This system can have an impact on the environment, one of which water pollution caused by leachate that is not well managed. The purpose of the research is to identify the quality of groundwater around the landfill and to determine the effect of landfill distance to water quality around Sungai Raya Landfill Site. Sampling was conducted in 3 areas around the landfill namely region $A$ with 6 sample points, region $B$ with 6 sample points and region $C$ with 6 sample points. The total sample point used is 18 points with each distance of 10 meters between points. The method used is through observation approach, analysis of laboratory results and statistical test with Minitab (Mann Whitney Test). The standard of water quality used is the standard of water quality class II in Government Regulation No. 82 Year 2001 which is intended for bathing, washing, and toilet activities. The result obtained states that in region $A$ the highest concentration value is at point $A 1$ which is the closest point to the stack of waste in landfill site with the concentration value of $C O D, P b, C d$ and total coliform respectively is $718,7 \mathrm{mg} / \mathrm{l} ; 0.03 \mathrm{mg} / \mathrm{l} ; 0.04$ $\mathrm{mg} / \mathrm{l}$; and $4300 \mathrm{MPN} / 100 \mathrm{ml}$, while the lowest concentration value is at point $\mathrm{A} 6$ which is point with thr distance of 50 meter from point $A 1$ with concentration value $C O D, P b, C d$ and total coliform respectively equal to $114,5 \mathrm{mg} / \mathrm{l} ; 0.01 \mathrm{mg} / \mathrm{l} ; 0,000 \mathrm{mg} / \mathrm{l}$; and $2850 \mathrm{MPN} / 100 \mathrm{ml}$. In region $B$ the highest concentration of concentration is at point $B 1$ which is the closest point to the stack of waste in landfill site with the concentration value of $C O D, P b, C d$ and total coliform respectively is 699,0 mg / /; $0.03 \mathrm{mg} / \mathrm{l} ; 0.02 \mathrm{mg} / \mathrm{l}$; and $3750 \mathrm{MPN} / 100 \mathrm{ml}$, while the lowest concentration value is at point $B 6$ which is the point with the distance of 50 meter from point B1 with concentration value of $\mathrm{COD}, \mathrm{Pb}, \mathrm{Cd}$ and total coliform respectively equal to $62,5 \mathrm{mg} / \mathrm{l} ; 0.00 \mathrm{mg} /$ l; $0,000 \mathrm{mg} / \mathrm{l}$; and $2650 \mathrm{MPN} / 100 \mathrm{ml}$. In region $C$ the highest concentration of concentration is at point $\mathrm{C} 1$ which is the closest point to the stack of waste in landfill site with the concentration value of $C O D, P b, C d$ and total coliform respectively is 700,3 mg / /; $0.03 \mathrm{mg} / \mathrm{l} ; 0.03 \mathrm{mg} / \mathrm{l}$; and $4950 \mathrm{MPN} / 100 \mathrm{ml}$, while the lowest concentration value is at point C6 which is the point with the distance of 50 meter from point $C 1$ with concentration value of $C O D, P b C d$ and total coliform respectively equal to 125,2 $\mathrm{mg} / \mathrm{l} ; 0.01 \mathrm{mg} / \mathrm{l} ; 0,000 \mathrm{mg} / \mathrm{l}$; and $3800 \mathrm{MPN} / 100 \mathrm{ml}$. The average concentration value of $C O D$ and total coliform at each point is above the class II water quality standard in Government Regulation No. 82 Year 2001, while the average concentration of $\mathrm{Pb}$ is below the limit of water quality standard II Government Regulation No. 82 Year 2001 and the value of the $C D$ at the point located within the landfill site is above the limit of water quality standard II in Government Regulation No. 82 Year 2001, and the value of Cd which is is outside the landfill site is below the threshold of water quality standard II in Government Regulation No. 82 Year 2001. Test results of Mann Whitney statistics show significant values of $>0.05$. This number indicates that there is a significant difference between the landfill distance to shallow ground water quality around Sungai Raya Landfill Site. Based on the analysis result, there is effect of landfill distance to shallow groundwater quality around Sungai Raya Landfill Site, which is indicated by if the shallow ground water is getting farther from landfill, the quality of shallow groundwater will get better.

Keywords: Leachate, shallow groundwater quality, landfill site

\section{PENDAHULUAN}

Lindi merupakan cairan yang banyak mengandung senyawa organik maupun anorganik, terbentuk dari dekomposisi sampah sehingga memiliki konsentrasi bahan pencemar yang tinggi (Parsons, 2002). Air hujan sebagian akan tertahan dan mengalir di permukaan tanah (run off) dan sebagian akan terinfiltrasi ke dalam rongga-rongga tanah. Air limpasan hujan (dari proses infiltrasi ataupun perkolasi) yang bercampur dengan sampah yang telah membusuk dan mengandung zat tersuspensi yang sangat halus akan menghasilkan cairann lindi. Infiltrasi air hujan dapat membawa kontaminan 
dari tumpukkan sampah dan memberikan kelembaban yang dibutuhkan bagi proses pembentukan lindi (Asdak, 2010).

TPA Sungai Raya merupakan TPA yang berada di Kecamatan Rasau Jaya, Kabupaten Kubu Raya yang dikelola oleh Dinas Kebersihan dan Pertamanan Kabupaten Kubu Raya. Luas TPA Sungai Raya sebesar 3,6 hektar. Sistem pengelolaan sampah yang diterapkan oleh TPA Sungai Raya yaitu secara open dumping dan belum memiliki pengolahan air lindi yang baik. TPA Sungai Raya terletak disekitar pemukiman penduduk. Sistem pengoperasian instalasi pengolahan lindi (IPL) yang dimiliki oleh TPA Sungai Raya tidak beroperasi dengan baik, karena tidak adanya kontrol dan monitoring yang rutin terhadap IPL yang mengakibatkan IPL tidak bekerja secara optimal. Selain itu, kondisi eksisting pada TPA Sungai Raya, masih banyak lindi yang mengalir dan menggenangi permukaan jalan pada TPA. Hal tersebut dapat berpotensi terhadap pencemaran lingkungan disekitar TPA, terutama pada kualitas air tanah dangkal disekitar TPA Sungai Raya. Oleh karena itu, perlu dilakukan suatu penelitian mengenai Identifikasi Kualitas Air Tanah Dangkal di Sekitar TPA Sungai Raya. Penelitian yang dilakukan bertujuan untuk mengidentifikasi kualitas air tanah dangkal disekitar TPA Sungai Raya berdasarkan parameter $\mathrm{COD}$, timbal( $\mathrm{Pb})$, kadmium (Cd), dan total coliform serta mengetahui pengaruh jarak TPA terhadap kualitas air tanah dangkal di sekitar TPA Sungai Raya.

\section{METODOLOGI PENELITIAN}

Pengambilan sampel penelitian dilakukan di TPA Sungai Raya, Kabupaten Kubu Raya dan analisis laboratorium dilakukan di Laboratrium Kesehatan Daerah Kalimantan Barat dan Laboratorium Kesehatan Lingkungan Fakultas Pertanian. Penelitian dilakukan dari bulan Mei-November 2017. Jenis penelitian yang dilakukan yaitu penelitian langsung dilakukan di lapangan. Pengambilan sampel dilakukan pada wilayah A (Selatan), wilayah B (Timur) dan wilayah C (utara) TPA. Masing-masing wilayah memiliki 6 titik pengambilan sampel dengan jarak 10 meter antar titik sampel, sehingga jumlah keseluruhan titik pengambilan sampel yaitu 18 titik sampel.

Alat yang digunakan dalam penelitian yaitu GPS (Global Positioning System), botol sampel (botol kaca),coolbox, bor tanah (hand bor), pipa PVC berdiameter 4 inci, pita ukur (meteran) 5 meter dan 50 meter, patok kayu ( \pm 1 meter). Pipa PVC berdiameter 4 inci berfungsi sebagai sumur pantau untuk pengambilan sampel air tanah dangkal, dengan panjang pipa yaitu 2 meter. Pengambilan sampel air tanah dangkal mengacu pada SNI-6989.58.2008 tentang Metode Pengambilan Sampel Air Tanah yaitu botol yang berukuran $600 \mathrm{ml}$ dimasukkan kedalam sumur hingga kedalaman 1,5-2 meter, kemudian masing-masing botol diberi kode sampel.

Analisis data yang digunakan yaitu analisis kualitas air dan analisis statistik. Analisis kualitas air digunakan untuk mengetahui konsentrasi parameter COD, timbal $(\mathrm{Pb})$, kadmium ( $\mathrm{Cd}$ ) dan total coliform pada air tanah dangkal TPA Sungai raya,dan dilakukan di laboratorium. Nilai konsentrasi parameter COD, timbal (Pb), kadmium (Cd) dan total coliform dari pengambilan sampel kemudian dibandingkan dengan baku mutu air kelas II pada PP No.82 Tahun 2001. Sedangkan analisis statistik yang digunakan yaitu dengan uji Mann Whitney pada Minitab. Uji Mann Whitney bertujuan untuk membandingkan kualitas air antara titik sampel satu dengan titik sampel lainnya. 


\section{HASIL DAN PEMBAHASAN}

\section{A) Pengukuran Muka Air Tanah}

Pengukuran muka air dilakukan untuk mengetahui tinggi muka air pada daerah pengambilan sampel. Pengukuran dan pengambilan sampel dilakukan pada musim kemarau. Hasil pengukuran menunjukkan tinggi muka air pada wilayah A berkisar antara 0,50-0,33 meter, wilayah B berkisar antara 0,4-0,20 meter dan wilayah C berkisar antara 0,55-0,31 meter. Nilai tersebut menunjukkan bahwa pada kedalaman 0,50 meter dari permukaan tanah disekitar wilayah pengambilan sampel sudah terdapat permukaan air tanah.

B) $\mathrm{COD}$

Nilai COD memberikan gambaran jumlah total bahan organik yang mudah terurai dan yang sulit terurai (non biodegradable). Hasil pengujian untuk parameter COD pada wilayah A, wilayah B dan wilayah C dapat dilihat pada Gambar 1.

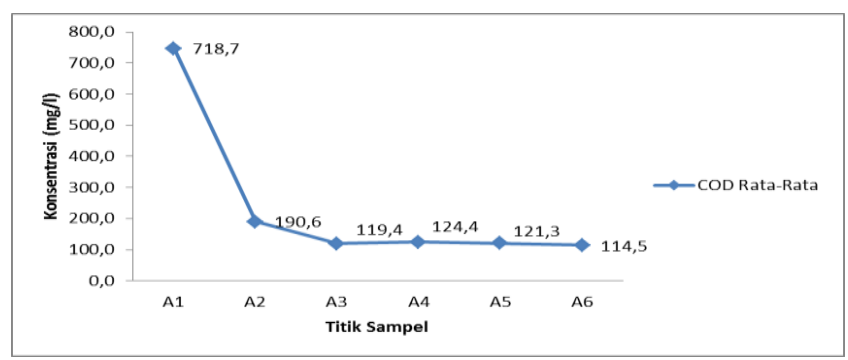

a. Nilai Rata-Rata COD Wilayah A TPA Sungai Raya

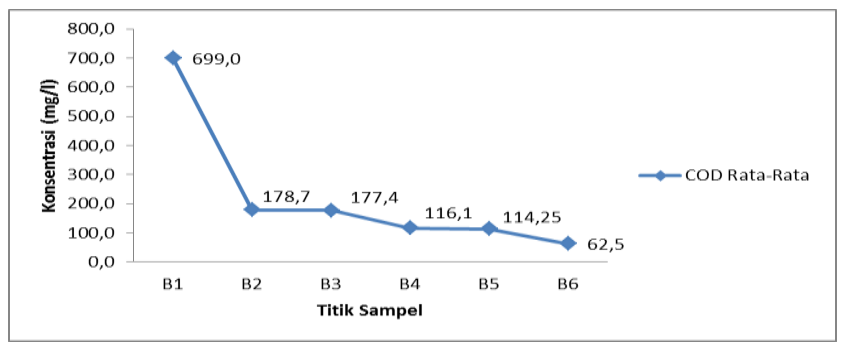

b. Nilai Rata-Rata COD Wilayah B TPA Sungai Raya

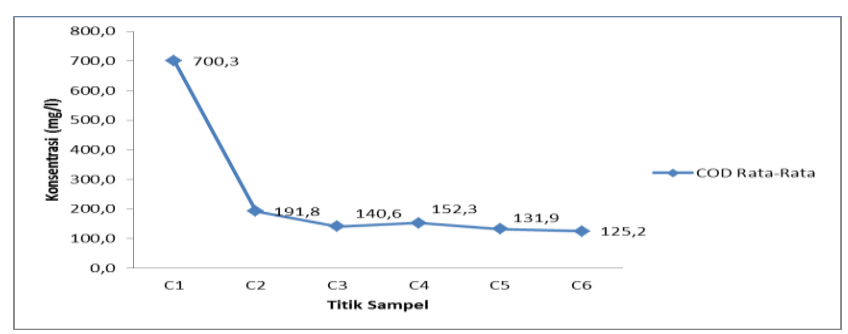

c. Nilai Rata-Rata COD Wilayah C TPA Sungai Raya

Gambar 1. Nilai Rata-Rata Konsentrasi COD TPA Sungai Raya

Hasil uji kualitas air berdasarkan parameter COD menunjukkan nilai konsentrasi untuk wilayah A, wilayah B dan wilayah $C$ dengan jarak 0-50 meter dari TPA 
menunjukkan adanya penurunan nilai konsentrasi namun masih berada di atas ambang baku mutu air kelas II pada PP No.82 Tahun 2001. Nilai COD tertinggi pada seluruh wilayah terletak pada titik sampel yang pertama.Tingginya nilai konsentrasi tersebut dipengaruhi oleh kondisi sekitar lokasi pengambilan sampel yaitu berada paling terdekat dengan tumpukkan sampah, sehingga rembesan lindi dapat memengaruhi kualitas air tanah dangkal disekitarnya. Sedangkan nilai konsentrasi yang terendah pada seluruh wilayah berada pada titik yang terjauh dengan jarak 50 meter dari TPA. Hal tersebut menunjukkan semakin jauh jarak TPA, semakin kecil pula dampak yang terjadi akibat dari aktivitas TPA. Penurunan nilai konsentrasi pada seluruh wilayah juga dipengaruhi oleh adanya tanaman jenis paku-pakuan dan tanaman scirpus grossus yang dapat menurunkan kadar COD pada air. Menurut Fitri (2008), tanaman scirpus grossus mampu menurunkan kadar COD pada air limbah sampah hingga 43,63\%.

\section{C) Timbal $(\mathrm{Pb})$}

Hasil pengujian logam timbal $(\mathrm{Pb})$ pada wilayah $\mathrm{A}$, wilayah $\mathrm{B}$ dan wilayah $\mathrm{C}$ dapat dilihat pada Gambar 2.

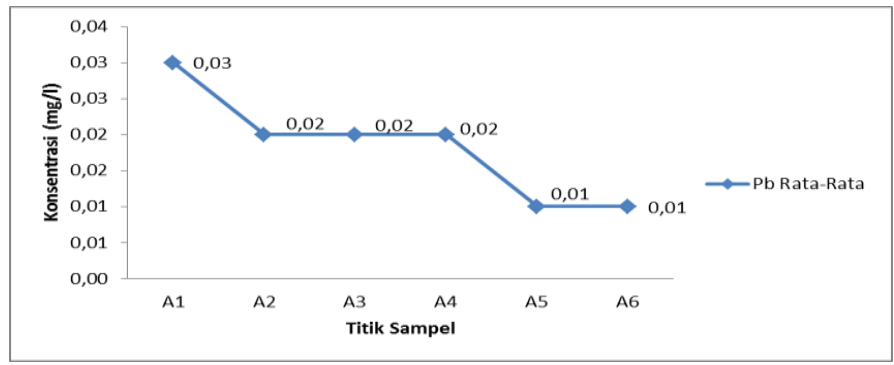

a. Nilai Rata Rata Timbal Wilayah A TPA Sungai Raya

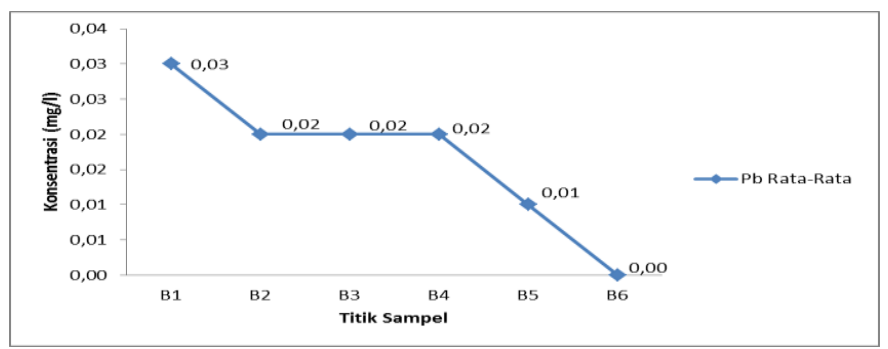

b. Nilai Rata Rata Timbal Wilayah B TPA Sungai Raya

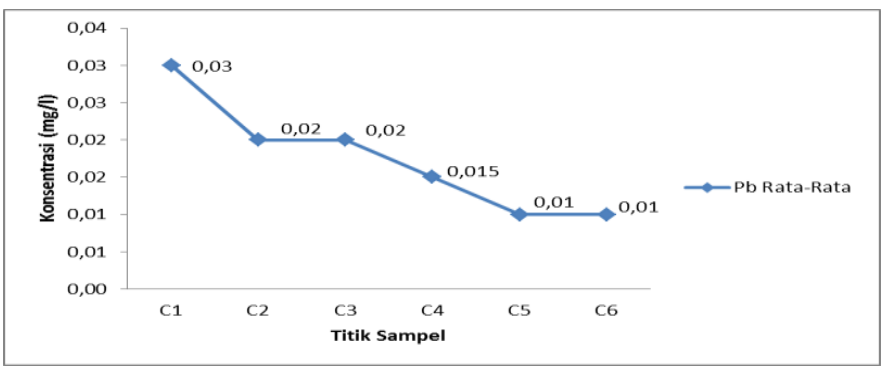

c. Nilai Rata Rata Timbal Wilayah C TPA Sungai Raya

Gambar 2. Nilai Rata-Rata Konsentrasi Timbal TPA Sungai Raya 
Berdasarkan hasil analisis logam timbal pada wilayah A, wilayah B dan wilayah C menunjukkan nilai konsentrasi timbal berada dibawah ambang batas baku mutu air kelas II PP. No 82 Tahun 2001. Nilai Pb tertinggi pada seluruh wilayah terletak pada titik sampel yang pertama.Tingginya nilai konsentrasi tersebut dipengaruhi oleh kondisi sekitar lokasi pengambilan sampel yaitu berada paling terdekat dengan tumpukkan sampah, sehingga rembesan lindi dapat memengaruhi kualitas air tanah dangkal disekitarnya. Sedangkan nilai konsentrasi yang terendah pada seluruh wilayah berada pada titik yang terjauh dengan jarak 50 meter dari TPA. Hal tersebut menunjukkan semakin jauh jarak TPA, semakin kecil pula dampak yang terjadi akibat dari aktivitas TPA. Menurut Putra (2010), hasil pemerikasaan terhadap kualitas kimia (logam) terbatas sumur yang diperiksa, menunjukka nilai kualitas air yang bervariasi. Nilai logam timbal yang semakin menurun pada semua wilayah pengambilan sampel juga disebabkan adanya tanaman keladi pada daerah sekitar pengambilan sampel. Batang keladi mampu menjadi bio sorben kandungan logam pada limbah cair (Ikhwan, 2015)

D) Kadmium (Cd)

Hasil pengujian logam kadmium (Cd) pada wilayah A, wilayah B dan wilayah C dapat dilihat pada Gambar 3.

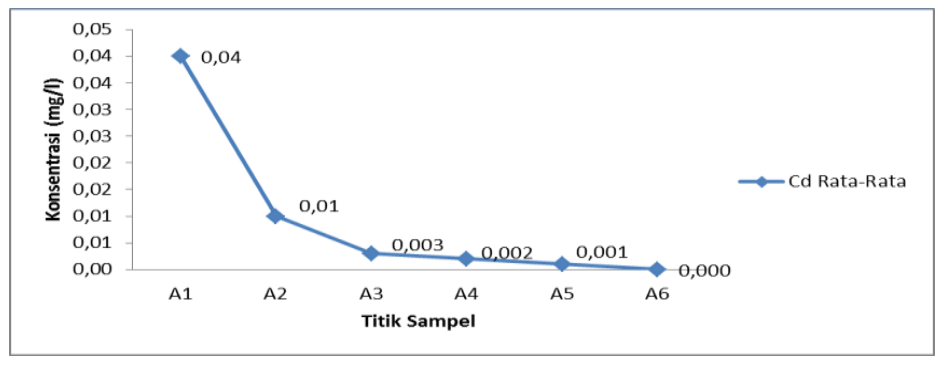

a. Nilai Rata Rata Kadmium Wilayah A TPA Sungai Raya

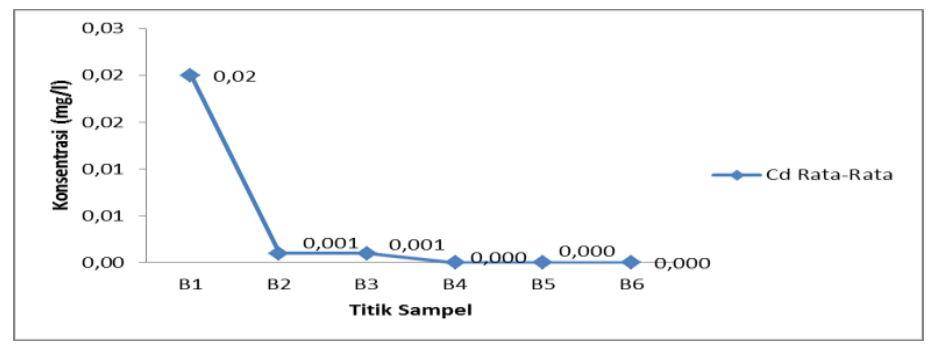

b. Nilai Rata Rata Kadmium Wilayah B TPA Sungai Raya

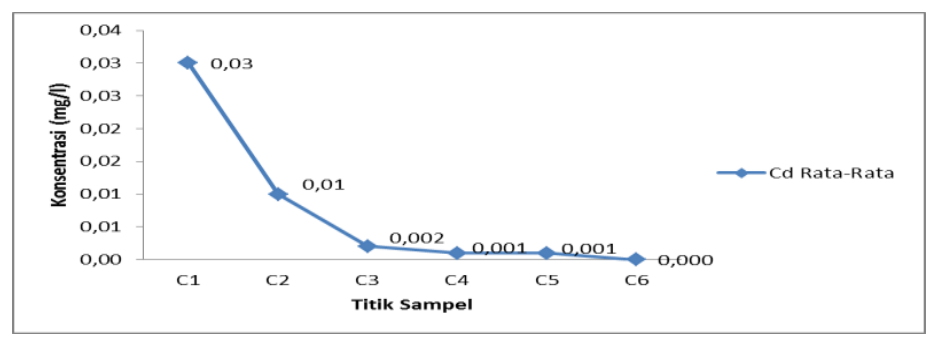

c. Nilai Rata Rata Kadmium Wilayah C TPA Sungai Raya

Gambar 3. Nilai Rata-Rata Konsentrasi Kadmium TPA Sungai Raya 
Hasil analisis logam kadmium pada wilayah A, wilayah B dan wilayah C menunjukkan nilai konsentrasi kadmium pada titik pertama melebihi ambang batas baku mutu air kelas II PP. No 82 Tahun 2001. Tingginya nilai konsentrasi tersebut dipengaruhi oleh kondisi sekitar lokasi pengambilan sampel yaitu berada paling terdekat dengan tumpukkan sampah, sehingga rembesan lindi dapat memengaruhi kualitas air tanah dangkal disekitarnya. Sedangkan titik sampel pada jarak 10-50 meter, nilai konsentrasi kadmium berada dibawah ambang batas baku mutu air kelas II. Nilai konsentrasi yang terendah pada seluruh wilayah berada pada titik yang terjauh dengan jarak 50 meter dari TPA. Hal tersebut menunjukkan semakin jauh jarak TPA, semakin kecil pula dampak yang terjadi akibat dari aktivitas TPA.

\section{E) Total Coliform}

Total coliform merupakan jumlah dari bakteri coli yang terdapat pada air. Jika didalam air ditemukan adanya bakteri, hal ini mengindikasi bahwa air tersebut tercemar dan memungkinkan mengandung bakteri patogen (Susanti dkk, 2000). Hasil pengujian total coliform pada wilayah A, wilayah B dan wilayah C dapat dilihat pada Gambar 4.

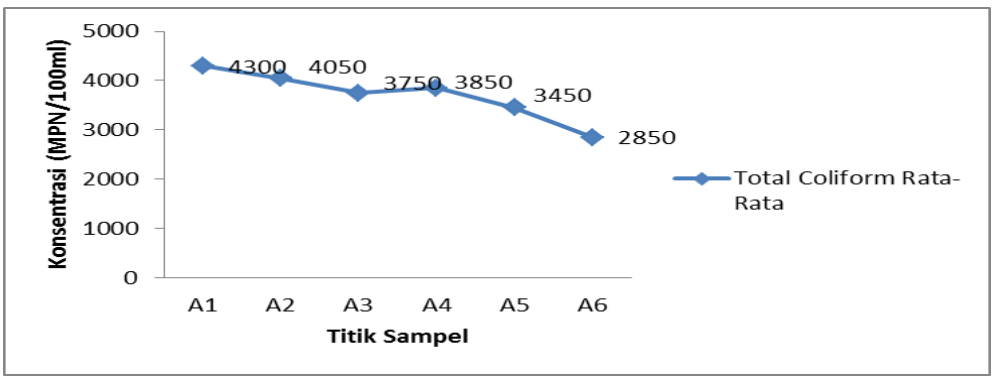

a. Nilai Rata Rata Total Coliform Wilayah A TPA Sungai Raya

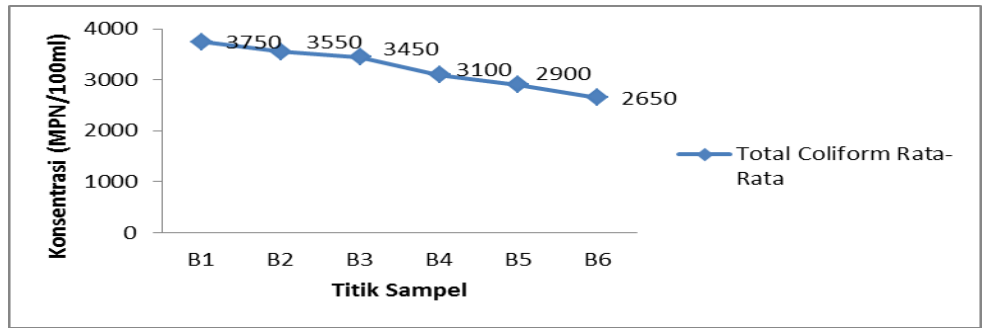

b. Nilai Rata Rata Total Coliform Wilayah B TPA Sungai Raya

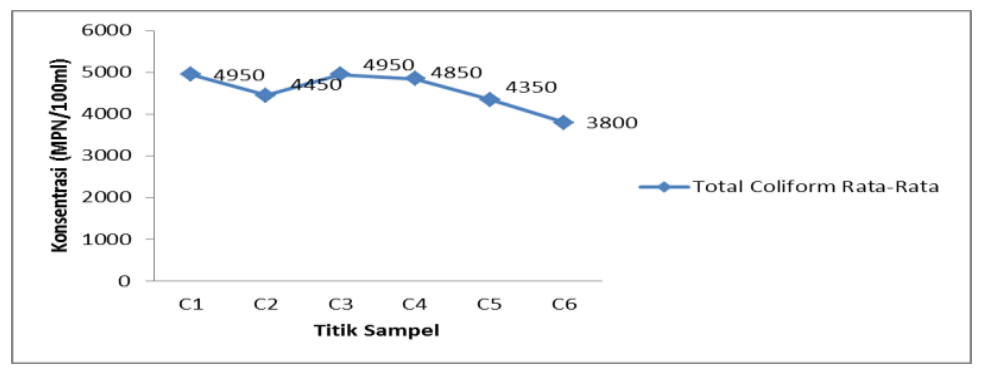

c. Nilai Rata Rata Total Coliform Wilayah C TPA Sungai Raya

Gambar 4. Nilai Rata-Rata Konsentrasi Total Coliform TPA Sungai Raya 
Hasil analisis total coliform pada wilayah A, wilayah B dan wilayah C menunjukkan nilai konsentrasi melebihi ambang batas baku mutu air kelas II PP. No 82 Tahun 2001. Nilai total coliform tertinggi pada seluruh wilayah terletak pada titik sampel yang pertama. Tingginya nilai konsentrasi tersebut dipengaruhi oleh kondisi sekitar lokasi pengambilan sampel yaitu berada paling terdekat dengan tumpukkan sampah, sehingga rembesan lindi dapat memengaruhi kualitas air tanah dangkal disekitarnya. Nilai konsentrasi total coliform yang terendah pada seluruh wilayah berada pada titik yang terjauh dengan jarak 50 meter dari TPA. Hal tersebut menunjukkan semakin jauh jarak TPA, semakin kecil pula dampak yang terjadi akibat dari aktivitas TPA.

Namun, pada wilayah C pada titik C3 terjadi kenaikkan konsentrasi dari titik sebelumnya, hal tersebut disebabkan oleh kondisi sekitar pengambilan sampel yang terdapat sumber pencemar seperti sisa aktivitas manusia dan kotoran hewan yang berasal dari kandang ternak warga sekitar. Menurut Bambang (2006), lokasi pengambilan sampel yang menunjukkan bahwa kandungan coliform bakteri bernilai tinggi disebabkan oleh lokasi pengambilan sampel yang banyak terdapat sampah yang bersumber dari sisa makanan, sisa-sisa tumbuhan, kotoran hewan dan manusia serta bangkai-bangkai hewan yang merupakan faktor utama tumbuhnya bakteri coliform.

\section{KONSISTENSI NILAI PARAMETER KUALITAS AIR TANAH DANGKAL}

Jenis metode statistik yang digunakan yaitu Uji Mann Whitney. Uji Mann Whitney merupakan uji non parametrik yang digunakan untuk menguji apakah dua buah sampel independen berasal dari populasi yang sama. Dalam menggunakan uji non parametrik Mann Whitney, yang harus dilakukan yaitu menentukan hipotesis berupa HO dan $\mathrm{H} 1$ pada penelitian. Pada penelitian ini, digunakan hipotesis HO yaitu jarak TPA tidak memengaruhi kualitas air disekitar TPA dan $\mathrm{H} 1$ yaitu jarak TPA memengaruhi kualitas air disekitar TPA. Tingkat signifikansi yang digunakan yaitu sebesar $5 \%$, yang memiliki arti bahwa pada penelitian ini tingkat kepercayaan bernilai $95 \%$ yang disesuaikan pada uji Mann Whitney. Apabila nilai signifikan $<\alpha$, maka keputusan menolak HO dan menerima $\mathrm{H} 1$. Sedangkan, apabila nilai signifikan $>\alpha$, maka keputusan menerima H1 dan menolak HO.

\section{A) Parameter COD}

Hasil pengujian Mann Whitney dengan menggunakan minitab untuk parameter COD dengan jarak 0-50 meter pada wilayah $A$, wilayah $B$ dan wilayah $C$ didapatkan nilai signifikansinya adalah 0,2453 di mana nilainya lebih besar dari batas kritis yang digunakan yaitu 0,05 sehingga keputusan menerima $\mathrm{H} 1$ yaitu jarak TPA memengaruhi kualitas air disekitar TPA. Kesimpulan yang didapat yaitu bahwa nilai konsentrasi pada titik A1-titik A6 memiliki nilai yang signifikan yang berarti terdapat perbedaan nyata antara jarak antar titik terhadap nilai konsentrasi COD dan memiliki nilai COD yang berada pada kisaran yang sama pada seluruh wilayah pengambilan sampel,yang tergolong kedalam klasifikasi melebihi baku mutu air kelas II menurut PP No.82 Tahun 2001.

\section{B) Total Coliform}

Hasil pengujian Mann Whitney dengan menggunakan minitab untuk parameter Total Coliform dengan jarak 0-50 meter pada wilayah A, wilayah B dan wilayah C didapatkan nilai signifikansinya adalah 0,2453 di mana nilainya lebih besar dari batas 
kritis yang digunakan yaitu 0,05 sehingga keputusan menerima $\mathrm{H} 1$ yaitu jarak TPA memengaruhi kualitas air disekitar TPA. Kesimpulan yang didapat yaitu bahwa nilai konsentrasi pada titik A1-titik A6 memiliki nilai yang signifikan yang berarti terdapat perbedaan nyata antara jarak antar titik terhadap nilai konsentrasi Total Coliform dan memiliki nilai Total Coliform yang berada pada kisaran yang sama pada seluruh wilayah pengambilan sampel,yang tergolong kedalam klasifikasi melebihi baku mutu air kelas II menurut PP No.82 Tahun 2001

\section{KESIMPULAN}

Kesimpulan dari penelitian adalah sebagai berikut:

1. Hasil analisis kualitas air tanah dangkal disekitar TPA Sungai Raya menunjukkan bahwa wilayah C (utara) memiliki nilai konsentrasi tertinggi yaitu parameter COD berkisar 700,3-125,2 mg/l; parameter Pb berkisar 0,03-0,01; parameter Cd berkisar 0,03-0,000 mg/l; dan parameter total coliform berkisar 4950-3800 MPN/100ml. Sedangkan wilayah B (timur) memiliki nilai konsentrasi terendah yaitu parameter COD berkisar 699,0-62,5 mg/l; parameter $\mathrm{Pb}$ berkisar 0,03-0,00; parameter $\mathrm{Cd}$ berkisar 0,02-0,000 mg/l; dan parameter total coliform berkisar 3750-2650 MPN/100ml.

2. Berdasarkan hasil analisis kualitas air tanah dangkal disekitar TPA, semakin jauh letak sumur dari TPA nilai kualitas air untuk parameter $\mathrm{COD}, \mathrm{Pb}, \mathrm{Cd}$ dan Total Coliform semakin menurun, yang berarti semakin jauh dari aktivitas TPA, maka kualitas air tanah dangkal semakin membaik. Hal tersebut menunjukkan bahwa terdapat pengaruh jarak sumur ke TPA Sungai Raya terhadap kualitas air tanah dangkal di sekitar TPA Sungai Raya

\section{SARAN}

Berdasarkan penelitian yang telah dilakukan, maka terdapat saran sebagai berikut

1. Perlu dilakukan penelitian lebih lanjut terhadap pemeriksaan kualitas air dengan memperhatikan faktor cuaca.

2. Perlu dilakukan penelitian lebih lanjut pengaruh kualitas air terhadap kesehatan lingkungan dan masyarakat sekitar.

\section{UCAPAN TERIMA KASIH}

Puji dan syukur kehadirat Allah SWT atas berkat dan rahmat-Nya sehingga saya dapat menyelesaikan penulisan skripsi saya. Terima kasih kepada dosen pembimbing saya Bapak Arifin dan Ibu Yulisa Fitrianingsih yang telah banyak memberikan bimbingan dalam penyelesaian skripsi saya, serta kepada dosen penguji Ibu Isna Apriani dan Bapak Hendri Sutrisno yang telah banyak memberikan saran dan kritik yang membangun dalam penyelesaian skripsi. Terima kasih juga saya ucapkan kepada pihak-pihak yang terlibat dan rekan-rekan yang telah banyak membantu dalam menyelesaikan skripsi saya. Semoga hasil penelitian ini dapat bermanfaat bagi semua pihak.

\section{DAFTAR PUSTAKA}

Asdak, Chay, 2010. Hidrologi dan Pengelolaan Daerah Aliran Sungai. Yogyakarta: GadjahMada University Press Yogyakarta. 
Peraturan Pemerintah Nomor 82. 2001. Pengelolaan Kualitas Air dan Pengendalian Pencemaran Air.

Standar Nasional Indonesia Nomor 6989.58.2008 tentang Metode Pengambilan Sampel Air Tanah.

Fitri, D.N., 2008. Fitoremidiasi Limbah Rumah Tangga Oleh Tanaman Wilgen (Scripuss Grossus), Kiapu (Pistia Stratiotes), dan Teratai (Nymphea). Program Studi Manajemen Sumber Daya Perairan. Fakultas Perikanan dan IImu Kelautan. Institut Pertanian Bogor.

Ikhwan, 2015. Efektifitas Biosorben Batang Keladi, Eceng Gondok, dan Batang Pisang Pada Limbah Cair Laundry. Fakultas Kesehatan Masyarakat. Universitas Andalas: Padang.

Putra, B. 2010. Analisa Kualitas Fisik, Bakteriologis Dan Kimia Air Sumur Gali Serta Gambaran Keadaan Konstruksi Sumur Gali Di Desa Patumbak Kampung Kecamatan Patumbak Kabupaten Deli Serdang. Skripsi. Universitas Sumatera Utara. Medan.

Bambang Kurniawan, 2006. Analisis Kualitas Air Sumur Sekitar Wilayah TPA Galuga Cibungbulang Bogor. Skripsi Fakultas Teknologi Pertanian : IPB. 